\title{
Generation of water quality index map using geographical information system
}

Pravin Dahiphale and Daleshwar Rajak

Received : 29.11.2017; Revised : 09.02.2018; Accepted : 18.02.2018

See end of the Paper for authors' affiliation

Correspondence to :

Pravin Dahiphale Department of S.W.E., Shramshakti College of Agricultural Engg. Maldad, Sangamner (M.S.) India Email : Pravin.dahiphale59 @ gmail.com
ABSTRACT : In this study different physico-chemical parameters such as $\mathrm{pH}$, electrical conductivity (EC), total dissolved solids (TDS), calcium $\left(\mathrm{Ca}^{+}\right)$, magnesium $\left(\mathrm{Mg}^{+}\right)$, sodium $\left(\mathrm{Na}^{+}\right)$, potassium $\left(\mathrm{K}^{+}\right)$, bicarbonate $\left(\mathrm{HCO}_{3}\right)$, carbonate $\left(\mathrm{CO}_{3}\right)$, chloride $\left(\mathrm{Cl}^{-}\right)$and sulphate $\left(\mathrm{SO}_{4}\right)$ present in pre and post-monsoon samples of the study area were determined using standard methods. Spatiotemporal variations of water quality parameters in the study area were analysed by using GIS techniques. The water quality index was computed by adopting the method of Tiwari and Mishra (1985) and Sinha and Saxena (2006) to determine the suitability of the groundwater for drinking purpose. The results show that in the pre monsoon period the 22.40 per cent area has good quality water for drinking purpose. The 61.62 per cent area has poor quality and 15.98 per cent area has very poor quality groundwater for drinking purpose. The 40.30 per cent has good quality and 59.70 per cent area has poor quality ground water for drinking purpose in post monsoon. The good quality water mainly occurred in East and middle portion of catchment area.

- KEY WORDS : GIS Techniques, Physico-chemical parameters

- HOW TO CITE THIS PAPER : Dahiphale, Pravin and Rajak, Daleshwar (2018). Generation of water quality index map using geographical information system. Internat. J. Agric. Engg., 11(1) : 60-63, DOI: 10.15740/HAS/IJAE/11.1/60-63. 